\title{
Audit exemption and the demand for voluntary audit: A comparative study of the UK and Denmark
}

\author{
Jill Collis \\ Brunel University
}

\begin{abstract}
This study investigates the sufficiency of turnover as a surrogate for demand for voluntary audit and compares the determinants in the UK and Denmark. Empirical data for the study were drawn from government surveys of the directors of small private companies in both countries, which were based on same research instrument. Bivariate tests support the hypothesized effects of turnover and a range of firm-specific factors suggested by economic rationality and agency theory. The main contribution of the study is the finding that turnover alone is not a sufficient surrogate for the costs and benefits of audit. The main predictors are turnover and a slightly different combination of management and agency factors in each country. The study provides a model that can be tested in other jurisdictions and its findings should be of interest to the accountancy profession and national regulators planning to introduce or revise audit exemption for small companies.
\end{abstract}

\section{Key words}

Audit exemption, Denmark, class B companies, small private companies, UK, voluntary audit

Correspondence to: Dr Jill Collis, Reader in Accounting, Brunel Business School, Brunel University, Uxbridge UB8 3PH, UK. Email: jill.collis@ brunel.ac.uk

\section{Acknowledgements}

The author is grateful to the anonymous reviewers for their guidance and to Professor Michael Bradbury (UNITEC Institute of Technology, Auckland, NZ) and Professor Len Skerratt (Brunel University, Uxbridge, UK) for helpful comments on the first draft of this paper. Thanks are also due to discussants at the AAA International Accounting Section Midyear Conference, Charleston and the EAA Annual Congress, Lisbon.

\section{Author profile}

Jill has conducted research for the Institute of Chartered Accountants in England and Wales, the Association of Chartered Certified Accountants, the Professional Oversight Board, the Department of Trade and Industry and the Department for Business, Enterprise and Regulatory Reform. Her work in the UK has contributed to regulatory impact assessments in Denmark, Finland, Norway and Sweden. 


\section{Summary}

The EU Fourth Directive allows Member States to grant exemption from the statutory audit to qualifying small companies within their jurisdictions. The UK introduced this option in 1994, but set the initial turnover threshold much lower than permitted. It was then raised in a series of steps until the EU maxima were adopted in 2004. Denmark waited until 2006 before introducing the option and also started with lower thresholds than the EU maxima. Little is known about the accounting and auditing needs of the directors of small private companies in Europe. Although there is an emerging literature for the UK and some other European countries, there is a significant gap in respect of Denmark in English language publications. This study addresses these deficiencies by investigating the sufficiency of turnover as a surrogate for demand for voluntary audit and comparing the determinants in the UK and Denmark.

The data are drawn from a government survey of the directors of small companies in Denmark (DCCA, 2005) that was based on the research instrument used for a similar survey commissioned by the UK's Department of Trade and Industry (Collis, 2003). The surveys found that in both countries more than $40 \%$ of the sample companies would choose voluntary audit if eligible for exemption. This could be interpreted simply as the influence of traditional action on economic rationality, but the bivariate tests in this study support the hypothesized effects of size and a range of management and agency factors suggested by economic rationality and agency theory.

A main contribution of the study is the finding that turnover alone is not a sufficient surrogate for the costs and benefits of audit. A logistic regression model identifies the main predictors as turnover (as a proxy for wealth at risk), combined with a slightly different combination of management and agency factors in each country. In both countries, management factors are that the cost of audit is not considered a substantial expense and it improves the quality of the financial information. In Denmark, an additional benefit is the check on accounting records and systems, which suggests that risk reduction is more important there. As far as the agency factors are concerned, meeting shareholders' needs for assurance is a factor in Denmark, but in the UK it was specifically associated with companies that are not wholly family-owned 
and, to a lesser extent, with companies that have external shareholders. This implies a lower level of trust in the UK. In Denmark, the benefit of audit in supporting agency relationships with the bank/lenders was significant at the $10 \%$ level, but was not significant for suppliers/creditors. The results for the UK companies were the reverse, which requires further investigation but may be due to increased use of behavioural scoring.

The study offers a model that can be tested in other jurisdictions and the results should be of interest to the directors of small companies, the accountancy profession and those planning to introduce or reviewing audit requirements in national or EU company law.

\section{Introduction}

The EU Fourth Company Law Directive (78/660/EEC) allows Member States to grant exemption from the statutory audit to qualifying small companies within their jurisdictions using size tests based on turnover, balance sheet total and number of employees. The UK introduced this option in 1994, but set the initial turnover threshold much lower than permitted. It was then raised in a series of steps until the EU maxima were adopted in 2004. Denmark waited until 2006 before introducing the option and also started with lower thresholds than the EU maxima.

Little is known about the accounting and auditing needs of the directors of small private companies. Although there is an emerging literature for the UK and elsewhere in Europe, there is a significant gap in respect of Denmark in English language publications. This study addresses that deficiency by investigating the sufficiency of turnover as a surrogate for demand for voluntary audit and comparing the determinants in the UK and Denmark. The data is drawn from a government survey of the directors of small companies in Denmark (DCCA, 2005) that was based on the research instrument used for a UK survey commissioned by the Department of Trade and Industry (Collis, 2003). The directors' views are important because they must weigh up the costs and benefits of external audit.

Audit is 'an independent examination of, and the subsequent expression of opinion on the financial statements' (Owen and Law, 2005, p. 34). It is designed to demonstrate 'the 
completeness, accuracy and validity of transactions which, when aggregated, make up the financial statements' (Power, 1997, p. 24). Exemption from statutory audit for small companies stems from recognition by the European Commission and national regulators that the burden of financial reporting falls disproportionately on small companies. It is rooted in the growing importance of small and medium-sized entities (SMEs) in the last 30 years. Since the recessions of the 1980s there has been considerable expansion in the population of small (0 to 49 employees) and medium (50 to 249 employees) entities. For example between 1980 and 2007, private sector entities in the UK grew from $2.4 \mathrm{~m}$ to $4.7 \mathrm{~m}$ (a rise of $96 \%$ ), mainly due to more micro entities (0 to 9 employees) and one-person companies (DTI, 1997; BERR, 2008). In the EU there are 23m SMEs (representing 99\% of all enterprises), which provide more than $100 \mathrm{~m}$ jobs. Therefore, it is not surprising that SMEs are referred to as 'the backbone of Europe's economy' (EC, n.d.) and that the European Commission is committed to policies to reduce administrative burdens on them by $25 \%$ by 2010 (EC, 2007).

The remainder of the paper is organised as follows: Section 2 describes the regulatory developments in audit exemption in the UK and Denmark, while section 3 reviews the literature and develops hypotheses based on empirical and theoretical assumptions. Section 4 explains the methodology and Section 5 presents the results. The paper concludes with comments on the contribution of the study and the implications of the results.

\section{Audit exemption in the EU}

\subsection{Overview}

The origins of the EU lie in post war Europe and the establishment of the European Economic Community by the Treaty of Rome in 1957 with a view to creating economic and political benefits through a common market. At that time there was considerable diversity in the regulation and practice of accounting and auditing. 'International trading, which had already long been a feature of European life, relied increasingly upon the services of the accountancy profession, but the nation-states dealt primarily with their empires rather than with each other. There was little reason to seek conformity in terms of infrastructures and controls' (Harding, 2000, p. 593). However, EU Directives set out to achieve harmonisation between Member States rather than universality, 'so that any remaining differences do not 
constitute an impediment to the EU's efficient operation' (Flower, 2004, p. 98). Over time, the need for financial reporting regulation to better reflect the modern business environment (Combarros, 2000) led to the endorsement of the majority of international accounting and auditing standards by the European Commission ${ }^{1}$ and this has increased the volume and complexity of regulation.

Article 51 of the Fourth Company Law Directive (78/660/EEC) requires all non-dormant limited companies to have their annual accounts audited. However, using the size criteria in Articles 11 and 27, national jurisdictions can provide exemption for qualifying non-publicly accountable small companies. Table 1 shows the proportion of small companies in the 19 Member States in 2003 that were likely to qualify. ${ }^{2}$

\section{Insert Table 1 about here}

The general size test for a small company is that it must not exceed any two of the three size thresholds for two consecutive years, but national jurisdictions can set lower thresholds if they wish. The EU maxima are subject to revision every five years for the purpose of indexation. Table 2 shows the EU maxima over the last 10 years and Chart 1 gives an indication of turnover thresholds adopted by the EU-25 at the end of 2005. ${ }^{3}$ Apart from Denmark, Sweden and Malta, all had incorporated the audit exemption option in their national accounting requirements, with the Netherlands, Germany and the UK using the EU maxima and the remainder used country-specific size criteria. However, the degree of variation shown in the table must be interpreted in the context that some countries were formerly in the Eastern bloc, but are now transition or emerging market economies (Day and Taylor, 2005). During the past few years, the audit exemption thresholds in some countries in Europe have been increased (sometimes from very low levels) or set for the first time (FEE, 2009). Table 3 provides the latest data for EU Member States, Norway and Switzerland.

Insert Table 2, Chart 1 and Table 3 about here 


\subsection{Similarities and differences between the UK and Denmark}

The UK and Denmark are well established market economies which joined the former European Economic Community in 1973. There are approximately $1.2 \mathrm{~m}$ small companies in the UK compared with $0.14 \mathrm{~m}$ in Denmark (BERR, 2008; DCCA, 2006, p. 3), but in both countries they account for the vast majority of the corporate sector (99\% and 95\% respectively). Whereas the UK and many other European countries have only one professional qualification in auditing, Denmark, Finland, Germany and Sweden have a twotier system 'allowing auditors with the lower qualification to audit only small and mediumsized firms' (Sundgren, 1998, p. 441). In the UK all practising auditors must be members of a professional body, but in Denmark membership of a professional society is not mandatory (Christiansen and Loft, 1992).

In some respects the UK appears to be an early adopter. For example the requirement to give a true and fair view has been part of UK company law since 1947, whereas the Danish et retvisende billede was not introduced until 1981; and although the Fourth Directive had allowed audit exemption since 1978, the UK waited 16 years before introducing it and Denmark waited 26 years. National accounting practices vary for a number of social, economic and cultural reasons (Haller and Walton, 1998), but research suggests that the UK and Denmark also have much in common. Gray's seminal article in 1988 draws on Hofstede's cross cultural research (1980 and 1983), which had placed the UK in the 'Anglo' culture area and Demark in the 'Nordic' culture area. Gray's framework incorporated the impact of culture on international differences in accounting and placed the Anglo and Nordic cultures in the same quadrant according to a number of paired accounting dimensions. Accordingly, accounting values in both countries are likely to favour 'professionalism' rather than 'statutory control' and 'flexibility' rather than 'uniformity'. In addition, they are likely to favour 'optimism' rather than 'conservatism' and 'transparency' rather than 'secrecy'.

Gray (1988) divided the extant literature into deductive studies that attempted to classify national systems of financial reporting (eg Mueller, 1967 and 1968; Nobes, 1983 and 1984) and inductive studies (eg Frank, 1979; Nair and Frank, 1980). Taking Nobes' updated scheme (1998) as an example of a deductive framework, this also groups the UK and Denmark together in what he labelled the 'micro/professional' category. Here countries are 
characterized by a legal system based on common law rather than Roman law, a large, old, strong accountancy profession, and financial reporting that is shareholder rather than tax oriented. Thus, companies strive 'to present fair information to outside users, without detailed constraint of law or tax rules but with standards written by accountants' (Alexander and Nobes, 2007, p. 66) and the general relationship between accounting and taxation is relatively weak (Alexander, Britton and Jorissen, 2007). This suggests that a comparative accounting study of the UK and Denmark is justified despite some differences.

A final point of note is that the UK data was gathered in the context of a well established option, whereas the Danish data was gathered in the context of introducing the option. Nonetheless, the issue was contentious in the UK also because the survey was assessing the impact of raising the thresholds to the much higher EU maxima. This is discussed next.

\subsection{The case of the UK}

Company law in the UK is shaped by national policies and influenced by EU Directives (Fearnley and Hines, 2003). For many years, the development of company law was the responsibility of the Department of Trade and Industry (DTI), but in mid-2007 it became the responsibility of the new Department for Business, Enterprise and Regulatory Reform (BERR). ${ }^{4}$ Differential reporting on the basis of size was introduced by the Companies Act 1981, which gave small and medium-sized private companies the option of registering abbreviated rather than full financial statements. Under the Companies Act 2006, ${ }^{5}$ a nonpublicly accountable company qualifies as small or medium if it meets any two of the three size tests based on turnover, balance sheet total and number of employees. Apart from a newly incorporated entity, the conditions must have been satisfied in two of the last three years. The conditions for total audit exemption are that the entity must qualify as small and meet both financial size tests.

Audit exemption was introduced in 1994 (SI 1994/1935) and allowed a company with a turnover up to $£ 90,000$ (lower than the EU maximum at that time), which qualified as 'small' for the purpose of filing abbreviated accounts, ${ }^{6}$ to forgo the statutory audit unless required by shareholders holding at least $10 \%$ of issued share capital. Companies with a turnover of between $£ 90,000$ and $£ 350,000$ were given the option of filing a simpler audit exemption 
report. This lesser form of assurance was dropped in 1997, leaving companies with a turnover up to $£ 350,000$ exempt from the statutory audit (SI 1997/936).

In 2000 the turnover threshold was increased to $£ 1 \mathrm{~m}$ (SI 2000/1430) and the government proposed raising the ceilings for all financial reporting purposes to the substantially higher EU maxima (DTI, 2000b). In accordance with their principle of evidence-based policy making (Cabinet Office, 1999), research was commissioned during the consultation period, including the Collis Report (2003), which provides the UK data analysed in this study. In January 2004, the financial thresholds were raised to the EU maxima, which for a small company were turnover of $£ 5.6 \mathrm{~m}$ and balance sheet total of $£ 2.8 \mathrm{~m}$ (SI 2004/16). In April 2008 , they were raised in line with the next EU revision to $£ 6.5 \mathrm{~m}$ turnover and $£ 3.26 \mathrm{~m}$ balance sheet total (see Chart 2).

\section{Insert Chart 2 about here}

\subsection{The case of Denmark}

Since 2004, there has been conformity between the Danish Financial Statements Act and the EU size thresholds and this brought approximately 1,700 more companies into the small category (accounting class B). Nevertheless, all companies, regardless of size were required to have an external audit (DCCA, 2005) and the only concession was an option for small and medium companies to abridge certain notes to the accounts (DCCA, 2006).

During the consultation process to assess the effect of abolishing or relaxing the statutory audit requirement for small companies, the Danish government commissioned the survey (DCCA, 2005) providing the data for this study. Following an intense political debate (DCCA, 2006), the Danish Folketing (Parliament) passed a bill in March 2006 exempting non-publicly accountable class B companies from the statutory audit if they do not exceed two of the following size criteria: turnover DKK 3,000,000 (€400,000), balance sheet total DKK 1,500,000 (€200,000), number of employees 12 (NRF, 2006, n.p.). These thresholds are considerably lower than the EU maxima shown in Table 2 but offer audit exemption to approximately 7,500 small companies (Holm and Warming-Rasmussen, 2008, p. 44). 


\section{Review of the literature}

In the UK, the vast majority of the financial reporting literature focuses on large listed companies. To a great extent, the limited amount of prior research in small private companies is due to the lack of a comprehensive, up-to-date sampling frame for unlisted companies and the low response rates that are typical in small business research (Curran and Blackburn, 2001). A search of the academic literature failed to locate any empirical evidence from Denmark, although linguistic constraints meant the search was restricted to English language publications. This suggests the present study will address an important information gap.

Among the few UK studies that have examined accounting or auditing issues for SMEs, generalisation is often not possible due to the small size of the sample or the exploratory nature of the research (for example, Freedman and Goodwin, 1993; Pratten, 1998; Seow, 2001). In addition, international comparisons can be problematic due to differences in accounting practices. The periodic raising of the EU maxima for indexation purposes also makes comparisons complex because the definitions of size can vary over time within a particular jurisdiction and between Member States at any one point in time. It also means that the results of earlier studies may not be relevant to the full range of companies included in a subsequent enlarged category of 'small' companies.

\subsection{Appropriateness of the thresholds in the UK}

It has been argued that audit exemption for small companies resolves the difficulty of developing and enforcing auditing standards on 'a widely diverse market, from ICI to the sweet shop and from Price Waterhouse to the sole practitioner' (Fearnley and Page, 1994, p. 81). The debate in the UK over the appropriateness of the audit exemption thresholds was dominated by anecdotal evidence from the regulators and the accountancy profession, with little consensus. For example, the Small Practitioners Association of the Institute of Chartered Accountants in England and Wales (ICAEW) survey of members in 1999 found 92\% supported 'exemption for all private, owner-managed, small limited companies' (Mitchell, 1999, p. 21). Their 2003 survey concluded there were 'few persuasive commercial, professional or statutory arguments why the European [turnover] threshold of $£ 4.8 \mathrm{~m}$ should not be introduced' (SPA, 2003, p. 3). The ICAEW described the proposal to raise the 
thresholds to the EU maxima as 'a positive step to ease the burdens on business' (Accountancy, 2003, p. 9). However, others in the ICAEW argued that doing so would reduce the quality of the information put on public record (Jones, 2003). The Association of Chartered Certified Accountants (ACCA) was against lifting the limits, arguing it would 'take away the value-added aspect which comes with the audit' (Beckerlegge, 1999, p. 21) and raise the risk of fraud (Rose, 2003).

\subsection{Take-up of audit exemption in the UK}

There are no official statistics on the proportion of UK companies taking up audit exemption in the early years. A MORI survey of 176 companies (ACCA, 1998) forecast that approximately $40 \%$ of companies with a turnover between $£ 350,000$ and $£ 1.5 \mathrm{~m}$ would opt for audit exemption if the threshold were raised to a speculative level of $£ 1.5 \mathrm{~m}$. Güntert (2000, p. 75) reported that at least $40 \%$ of those eligible when the turnover threshold was $£ 350,000$ were having a voluntary audit, implying a take-up rate of $60 \%$. He adds that it is not clear whether these companies were deliberately choosing to continue with an audit or simply didn't realise that it wasn't needed!' In 2003, the DTI estimated that $68 \%$ of companies with a turnover up to $£ 1 \mathrm{~m}$ had taken advantage of audit exemption (DTI, 2003) and raising thresholds to the EU maxima would add a further 8\% (DTI, 2003, Annex B, p. 4; Eaglesham, 2003). As Tauringana and Clarke (2000) point out, statistics for the proportion of companies that qualify as small under company law are not available. Estimates for 2004-5 (after thresholds were raised to the EU maxima), suggest that $80 \%$ of non-dormant small companies registered audit exempt financial statements, leaving $20 \%$ choosing voluntary audit (POB, 2006, p. 32).

\subsection{Size}

In both the UK and Denmark, the political rationale for introducing audit exemption was to reduce compliance burdens, which fall disproportionately on small companies (DTI, 1995; DTI, 1999b, DCCA, 2005). Implicit in this argument is the notion that below a certain size, the costs outweigh the benefits. In the UK, the Trade Secretary claimed the average company would save $£ 5,000$ from discontinuing the audit, but the accountancy profession responded that a more realistic figure was between $£ 1,200$ and $£ 1,500$ (Güntert, 2000). 
A survey of 790 small private companies in the UK (Collis, 2003) found that cost was a factor for those deciding to discontinue the audit, but only 43 were able to provide a figure for the amount saved. The mode was $£ 1,000$, which matched the modal audit fee disclosed in the previous year's accounts. However, case study evidence from auditors suggests that in many cases the audit fee is a broad estimate, due to the overlap with accounts preparation work (Marriott, Collis and Marriott, 2006). If the company decided to forgo the audit, it is likely that the preparation fees would rise. Costs would also rise if ethical standards required accounts preparation and audit work for small companies to be conducted by separate firms (Collis and Jarvis, 2005). There is evidence that the majority of small companies in the UK and Denmark use an external accountant to prepare their annual financial statements. In 2003, $85 \%$ of small companies used an external accountant (Collis, 2003); in Denmark the proportion in 2004 was $83 \%$ (DCCA, 2005). ${ }^{7}$

In Denmark, there were concerns in 2004 that audit fees would rise by $20 \%$ to $30 \%$ due to the increase in international accounting and auditing standards, which were principally aimed at large, listed companies (DCCA, 2005). The government recognised that the burden would be proportionately larger for the growing number of small companies and expressed doubt that 'increased control of internal procedures could be carried out meaningfully in small companies with no employees or so few that the cashier function is their accounts administration' (DCCA, 2005, p. 5).

The role of firm size as a determinant of financial reporting disclosure by listed companies is unclear (for example, Cormier, Magnan and Van Velthoven, 2005). Nevertheless, it is widely argued that costs increase in proportion to the size of the business due to increased separation of ownership and control and greater complexity of operations (Simunic and Stein, 1987; Ettredge et al., 1994). A study of 92 small private companies in the UK by Tauringana and Clarke (2000) found evidence of the effect of firm size on the demand for voluntary audit in respect of turnover, but not balance sheet total or liquidity. A larger survey (385 small private companies with a turnover up to $£ 4.2 \mathrm{~m}$ filing full accounts) found turnover, but not balance sheet total or number of employees, was a significant predictor of voluntary audit (Collis, Jarvis and Skerratt, 2004). This leads to the following cost hypothesis that larger companies are more likely to be able to afford voluntary audit: 


\subsection{Management factors}

It is management's responsibility to weigh up the costs and benefits of the financial reporting options available to the company and it is logical to assume that the decision is based on economic rationality. The classical model of rationality was proposed by Weber (1968) and developed by others such as Hargreaves Heap (1989). Weber's model is based on formal rationality (actions which can be understood because they can be interpreted in terms of some calculative model), which is influenced by substantive rationality (a person's goals, principles or values), traditional action arising from habit or custom and affective action arising from emotion (Jarvis, Kitching, Curran, and Lightfoot, 1996). This provides a context for considering the benefits of voluntary audit to management.

'Audit is a risk reduction practice' (Power, 1997, p. 5). An independent audit of internal controls can reduce information risk, inherent risk (the likelihood of a material misstatement arising) and control risk (the likelihood of the accounting control detecting any material misstatement), thereby reducing agency costs (Hossain, Perera and Rahman, 1995; Watson, Shrives and Marston, 2002; Prencipe, 2004). Whilst audit does not set out to detect fraud, it can play a key role in detecting material fraud and deterring potential fraudsters (Güntert, 2000; Ramos, 2003). In some companies, inherent risk and control risk may be high. For example a study of 103 private companies in the USA found that owner-managers demanded voluntary audit 'as compensatory control systems for the organizational loss of control inherent in hierarchical organizations' (Abdel-Khalik, 1993, p. 31). Demand was also associated with turnover or total assets to represent the value of wealth at risk and was associated with demand by lenders, which increased the amount owners were willing to pay for audit assurance.

Güntert (2000, pp. 75 and 76) argues that the small company audit gives the directors 'increased confidence in the reported figures, the general financial position of the business, the financial basis for making decisions, the reliability of the accounting system and the information it produces, and the early identification of trends that could lead to failure'. 
These views are supported by empirical evidence from the UK (Collis et al., 2004), which found demand for voluntary audit is positively associated with the benefits of having an annual check on internal systems and records, and the improved quality of the information in the accounts.

The following management hypotheses are based on the assumption that the directors make rational decisions based on weighing up the relative cost of audit versus the benefits of reducing information risk, inherent risk and control risk:

H2 Ceteris paribus, voluntary audit is inversely associated with the directors' perceptions of cost as a substantial expense.

H3 Ceteris paribus, voluntary audit is positively associated with the directors' perceptions that it provides a beneficial check on accounting records and systems.

H4 Ceteris paribus, voluntary audit is positively associated with the directors' perceptions that it improves the quality of financial information.

\subsection{Agency factors}

Agency theory (Jensen and Meckling, 1976) offers further explanation for the directors' motivation to have an external audit. It rests on the proposition that where there is information asymmetry in economic contracts between principal and agent, the agent will be willing to bear the cost of supplying information to support the relationship. Audit supports agency relationships by providing information to reduce uncertainty. According to Power (1997), a principal is anyone who is distant from the actions of management and is unable to verify those actions, such as external shareholders, lenders and creditors. He contends that information asymmetry can be present amongst internal shareholders if they lack the necessary skills to interpret financial information.

There is still a considerable gap in the literature on the users of the financial statements of small companies since this was highlighted by Jarvis (1996). Surveys in Italy (Paoloni and Demartini, 1997) and Finland (Riistama and Vehmanen, 2004) identify the main users as management, the tax authorities and banks, with the two latter groups representing public interest (Evans, Gebhardt, Hoogendoorn, Marton, Di Petra, Mora, Thinggård, Vehmanen, and 
Wagenhofer, 2005). A Swedish study (Svensson, 2003) shows that banks use financial information as the basis of credit rating and this appears to be mandatory in Germany where 'banks are required by law to consider financial statements in their decisions, if the credit amount is higher than 750,000 Euro' (Haller and Löffelmann, 2008, p. 3).

According to the DCCA (2006, p. 4), the most important external users of financial statements in Denmark are credit institutions (lenders), trade creditors and the tax authorities. Banks are the most important providers of finance and $48 \%$ of small companies are funded by bank loans. Although the ability of the business to repay the loan and the future value of assets are important, the bank's knowledge of the customer is the key factor in the lending decision, importance is also attached to the accounts being prepared by a reputable auditor.

Empirical evidence from the UK (Page, 1984; Carsberg, Page, Sindall and Waring, 1985) and Ireland (Barker and Noonan, 1996) shows that the directors are the main users of the statutory accounts and a UK study shows they are used for a range of internal and external purposes (Collis and Jarvis, 2000 and 2002). The recipients of the annual financial statements in the UK are the bank/lenders, tax authorities, managers who are not shareholders and suppliers/trade creditors (Collis and Jarvis, 2000). This suggests the main user groups are similar to many of those identified by the conceptual framework for large, listed companies (IASC, 1989). The accounts are audited to help control the conflict of interest among managers, shareholders and outside creditors' (Tauringana and Clarke, 2000, p. 160) and the usefulness of audit to these groups is confirmed by other studies of small companies and accountants (POB, 2006). Collis et al., (2004) identify the key agency relationships having an impact on demand for voluntary audit as those with the bank/lenders and with shareholders in companies that are not wholly family-owned.

Collis et al. (2004) argue that leverage is a noisy proxy for the agency demand for audited accounts by lenders. For example, an Australian study (Carey, Simnett and Tanewski, 2000) found level of debt and proxies for the separation of control from ownership were significant determinants of demand for voluntary audit. In the USA, a study of listed companies in 1926 before statutory audit was introduced (Chow (1982) obtained significant results for leverage as a proxy for the use of accounting numbers in debt covenants and, to a lesser extent, size. 
On the other hand, Ettredge, Simon, Smith and Stone (1994) found leverage was not significant in explaining the demand for quarterly reviews prior to filing with the SEC, whilst other studies (for example, Dichev and Skinner, 2002) have used leverage as a proxy for the closeness of a company to the constraints specified by the debt covenants.

The following agency hypotheses are based on the contention that companies demand voluntary audit to meet the needs of shareholders, lenders and suppliers/creditors:

\section{Agency factors:}

H5 Ceteris paribus, voluntary audit is positively associated with supporting an agency relationship with shareholders (subsidiary hypotheses test whether this association is affected by family ownership or having external shareholders).

H6 Ceteris paribus, voluntary audit is positively associated with supporting an agency relationship with the bank/lenders.

H7 Ceteris paribus, voluntary audit is positively associated with supporting an agency relationship with suppliers/creditors.

\section{Methods}

The study addresses two research questions:

- What is the sufficiency of turnover as a proxy for the demand for voluntary audit assurance by the directors of small private companies in the UK and Denmark?

- Do the main determinants of voluntary audit in small private companies differ between the UK and Denmark?

\subsection{Data collection}

In the UK, a random sample of 2,633 companies was selected from FAME, a database drawn from the accounts registered at Companies House (Collis, 2003). It comprised active, independent, non-publicly accountable companies, which were selected if they met all three of the EU size criteria for a small company at that time (see Table 2). The data was collected via a postal questionnaire in April 2003. After one reminder, 790 usable replies were 
received, giving a response rate of $30 \% .^{8}$ Although tests for non-response bias found nonrespondents were likely to have been smaller in terms of number of employees, the sample was representative in terms of turnover and balance sheet total.

In Denmark, a statistically representative sample of 1,671 active, non-publicly accountable B companies was drawn from the DCCA register (DCCA, 2005). The companies were selected if they met any two of the three EU size criteria for a small company at that time (see Table 2). A postal questionnaire was sent in May 2004 with one reminder, which allowed the opportunity to respond via the internet or telephone. A total of 553 usable replies were received by mail, internet or telephone, representing a response rate of $33 \%$.

\subsection{Variables in the analysis}

The analysis takes the form of a logistic regression study using the following general model:

Voluntary audit decision $=\mathrm{f}($ size, management factors, agency factors $)$

Table 4 describes the variables in the analysis.

\section{Insert Table 4 about here}

The dependent variable (VOLAUDIT) is a dummy variable (coded 1, 0) that captures whether the directors would have a voluntary audit if the company were eligible for exemption and is drawn from the survey data. The UK sample included companies that might already qualify for exemption, together with others that might become eligible if the thresholds were raised to the EU maxima. The Danish sample consisted of companies that might qualify for exemption if it were introduced using the EU maxima. An advantage of using a variable based on a predicted decision in a hypothetical situation is that it captures views on the relative value of audit, without the complication of the qualification criteria and any country differences in accounting regulation. Nevertheless, there are some reservations since the predictions may not be accurate. However, the reliability and validity of the measure is strengthen by comparing the forecasts made by the UK companies with the choices made the previous year, which shows a difference of only 1\% (Collis, 2003). 
Size

The source of the UK data for TURNOVER was the 2002 financial statements on FAME, which was converted to $£$ million to aid the interpretation of the results. The Danish data for TURNOVER was taken from the survey in that country and was measured in DKK million size bands. Because the size bands were unequal $(<0.5 ; 0.5$ to $1.9 ; 2$ to $4.9 ; 5$ to $11.9 ; 12$ to $24.9 ; 25$ to $57.9 ; \geq 58$ ), the measurement scale is ordinal rather than interval. Tauringana and Clarke (2000) and Collis et al. (2004) found turnover was the key size variable in this context. The focus on relieving the disproportionate burden placed on small companies in company law suggests turnover captures costs. However, some research suggests an agency perspective, as turnover was a significant factor when used as a proxy for separation of ownership and control (Chow, 1982; Tauringana and Clarke, 2000) or a measure of value of wealth at risk (Abdel-Khalik, 1989).

\section{Management factors}

Economic rationality (Weber, 1968, Hargreaves Heap, 1989) underpins the management factors examined in the analysis: COST, CHECK and QUALITY. These variables are based on survey data measured on an ordinal scale $(5=$ agree; $1=$ disagree $)$. In this study, COST is not a financial measure, but a construct based on perceptions of the relative cost burden. This offers the advantage of providing a common unit of measurement in an international study. It also improves the validity of the results, since some of the UK companies may never had their accounts audited, which would mean actual costs are not available, whilst others may have discontinued the audit some years earlier, which would mean only historic data would be available. The reliability of historic data would depend on whether the amount and year could be obtained or recalled accurately and adjusted to reflect current costs. Another problem is that the figure disclosed in the accounts might not be an accurate reflection of audit costs, since the fees are likely to overlap if the same firm prepares and audits the accounts (Collis, 2003; Marriott et al., 2006). Previous research finds two specific benefits to management arising from audit: the check on internal books and records and the improvement in the quality of the information (Collis et al., 2004). In this study, CHECK and QUALITY capture these two benefits. Agency theory (Jensen and Meckling, 1976) suggests these would reduce information risk, control risk and inherent risk, which would lower 
agency costs (Hossain, Perera and Rahman, 1995; Watson, Shrives and Marston, 2002; Prencipe, 2004), thereby contributing to an economically rational decision.

\section{Agency factors}

Previous research suggests voluntary audit plays a role in controlling any conflict of interest between the directors, shareholders and outside creditors (Tauringana and Clarke, 2000; Collis et al, 2004). SHAREHLDRS, FAMILY, EXOWNERS, BANK and CREDITORS are dummy variables (coded 1,0) based on the survey data, which capture the role of audit in supporting agency relationships. SHAREHLDRS measures the demand for audit by the shareholders, whilst FAMILY and EXOWNERS measure the influence of family ownership and the separation of ownership and control respectively. BANK and CREDITORS capture the role of the audited accounts in supporting agency relationships with the bank/lenders and suppliers/creditors.

The regression analysis was preceded by preliminary tests of association and difference between the two groups in the dependent variable and each independent variable (nonresponses were excluded). Non-parametric tests were used because the variables were measured on a ratio scale with a non-normal distribution or on a nominal or ordinal scale, thus failing to meet the basic assumptions of parametric statistics. These require variables to be measured on a metric scale, drawn from a population with a normal distribution and to demonstrate homogeneity of variance and independence between variables (Field, 2000).

Table 5 provides descriptive statistics for the variables in the analysis. Strictly speaking, the mean cannot be calculated for ordinal data, since the ranks represent nominal categories and is given merely as an indication of central tendency. Table 6 presents a correlation matrix of the ordinal and ratio independent variables, which was examined for evidence of collinearity. ${ }^{9}$ The results are satisfactory since none of the correlation coefficients indicate high levels that would increase the probability that a good predictor of an outcome being found non-significant (Kervin, 1992).

\section{Insert Tables 5 and 6 about here}




\section{Results}

\subsection{Univariate analysis}

In the UK 'the large majority of companies have a turnover of less than $£ 250,000$, with the numbers larger than this tailing off dramatically. Equally importantly, the majority (over half a million) have only one or two shareholders' (DTI, 2000a, p. 270). Table 7 confirms that the vast majority of the UK and Danish companies were indeed at the smaller end of scale according to several measures of size. In addition, most were closely held since few had external shareholders and the large proportion were wholly family-owned or one-person businesses.

\section{Insert Table 7 about here}

In the UK $57 \%$ of the companies supported the government's proposal to raise the thresholds for audit exemption to the EU maxima for a small company. In Denmark $31 \%$ were in favour of giving audit exemption up to the EU maxima for a small company and $33 \%$ were in favour of making it available to the smallest companies only or for those with a record of unqualified annual or tax accounts (DCCA, 2005). The dependent variable (VOLAUDIT) is based on whether the company would have a voluntary audit if it were eligible for exemption. The proportions in both countries were remarkably similar: $43 \%$ of directors in the UK and $41 \%$ in Denmark. The remaining Danish companies (59\%) would either stop having an audit or choose a less extensive form of assurance if an alternative were available. ${ }^{10}$

\subsection{Preliminary tests}

Mann-Whitney tests were conducted to examine the independence of the two groups in the dependent variable VOLAUDIT and the independent variables measured on a non-parametric ratio scale (TURNOVER) or ordinal scale (COST, CHECK, QUALITY). As can be seen in Table 8 , all the results are significant $(p \leq .01)$.

\section{Insert Table 8 about here}


Chi-square tests were used to measure the association between the two groups in the dependent variable (VOLAUDIT) and the independent variables measured on a dichotomous nominal scale (SHAREHLDRS, FAMILY, EXOWNERS, BANK, CREDITORS). Table 9 shows significant results $(p \leq .01)$ for all variables in respect of the UK companies. However, FAMILY and EXOWNERS are not significant for the Danish companies.

\section{Insert Table 9 about here}

\subsection{Sufficiency of turnover}

The logistic regression models in Table 10 examine the sufficiency of turnover as a surrogate for the management and agency factors as predictors of voluntary audit:

- In Panel A size, as measured by TURNOVER, is used as the sole predictor. For both countries, the results are highly significant $(p \leq .01)$, but the pseudo $\mathrm{R}^{2}$ indicates that the model explains only $18 \%$ of the variance in the two groups in VOLAUDIT for the UK companies and 3\% for the Danish companies.

- In Panel B the size and management factors are regressed and TURNOVER is used as a proxy for the agency factors All the results are highly significant $(p \leq .01)$ and the regression coefficient (B) for COST shows the expected negative relationship with VOLAUDIT. The pseudo $\mathrm{R}^{2}$ indicates an improved goodness of fit compared with Panel A, explaining $40 \%$ of the variance for the UK companies and $46 \%$ for the Danish companies.

- In Panel $\mathrm{C}$ the size and the agency factors are regressed and TURNOVER is used as a proxy for the management factors. The results for the UK companies show that the regression coefficient (B) for FAMILY has the expected negative sign and the results for the agency variables are significant $(p \leq .05)$, apart from BANK, which is not significant. The results for the Danish companies are highly significant $(p \leq .01)$ apart from TURNOVER which is significant at the $10 \%$ level $(p \leq .10)$. The pseudo $\mathrm{R}^{2}$ also indicates an improved goodness of fit compared with Panel A. This third model explains $42 \%$ of the variance for the UK companies, but only $29 \%$ for the Danish companies. 


\subsection{Size, management and agency factors}

The final model shown in Table 11 identifies the significant predictors of voluntary audit when the size, management and agency factors are entered into a multiple regression model:

Size

The results for TURNOVER are significant $(p \leq .05)$ and provide evidence to reject the null hypothesis for $\mathrm{H} 1$ in both countries.

\section{Management factors}

The results for COST and QUALITY in both countries are significant $(p \leq .05)$ and the correlation coefficient (B) for COST has the expected negative sign. This is evidence to reject the null hypotheses for $\mathrm{H} 2$ and $\mathrm{H} 4$ in both countries. The result for CHECK is highly significant for the Danish companies $(p \leq .01)$, but not significant for the UK companies, which is evidence to reject the null hypothesis for H3 in Demark.

\section{Agency factors}

The result for SHAREHLDRS is highly significant for the Danish companies $(p \leq .01)$, but not for the UK companies, which provides evidence to reject the null hypothesis for H5 for Denmark. In respect of the UK companies, the correlation coefficient for FAMILY carries the expected negative sign and the result is highly significant $(p \leq .01)$. The UK result for EXOWNERS is significant at the $10 \%$ level $(p \leq .10)$. Therefore, the null hypothesis for H5 in respect of family ownership and external shareholders is rejected for the UK companies. BANK is significant at the $10 \%$ level for the Danish companies only, whereas CREDITORS is significant at the $10 \%$ level for the UK companies $(p \leq .10)$. This provides evidence to reject the null hypothesis for $\mathrm{H} 5$ in respect of the bank/lenders in Denmark and suppliers/creditors in the UK.

Examining the goodness of fit, the pseudo $\mathrm{R}^{2}$ indicates that the model is superior to those in Table 10, explaining 54\% of the variance in the UK companies and 53\% in the Danish companies. 


\section{Conclusions}

\subsection{Contribution and discussion}

This comparative study contributes to the meagre literature on the accounting and auditing needs of the directors of small private companies in Europe by investigating the sufficiency of turnover as a proxy for the voluntary demand for audit assurance and the main determinants of voluntary audit in the UK and Denmark. It has analysed empirical data from a government sponsored survey of the directors of small companies in Denmark (DCCA, 2005) that was based on the questionnaire used for a similar survey commissioned by the UK government (Collis, 2003). The focus of the UK survey was on the impact of raising the thresholds for audit exemption to the EU maxima, whereas the Danish survey was on the first time adoption of audit exemption. The large size of the samples (UK 790; Denmark 553) and high response rates (UK 30\%; Denmark 33\%) compared with many other SME studies both add to the reliability of the results.

Despite audit exemption being available to most small private companies in the UK for nearly a decade, and being a new phenomenon in Denmark, the directors of a significant proportion of companies in both countries ( $43 \%$ and $41 \%$ respectively) predicted the company would have a voluntary audit. This behaviour could be explained as the influence of traditional action on economic rationality (Weber, 1968), but the study identifies other determinants.

Whilst turnover alone can predict audit demand in both countries, it is not a full and sufficient surrogate for the motivation of the directors to opt for voluntary audit (Table 10). The final model (Table 11) supports the hypothesized effects of size as measured by turnover and a range of management and agency factors, which differ slightly between the two countries. Abdel-Khalik (1989) argued that turnover is a proxy for the wealth at risk, whilst others (Simunic and Stein, 1987; Ettredge et al., 1994) have suggested it represents agency costs and the separation of ownership and control, which increase in proportion as a result of more 
complex operations and greater delegation of control. Since relative cost and agency factors were included in the model, Abdel-Khalik's explanation is adopted, but the role of turnover is uncertain and requires further investigation.

In both countries, the management factors determining voluntary audit are that cost is not considered a substantial expense and audit provides the benefit of improving the quality of the financial information. The latter confirms previous research in the UK (Collis et al., 2004). In Denmark, an additional benefit is the check on accounting records and systems, which also supports Collis et al. (2004), although it was not significant for the enlarged category of UK companies. ${ }^{11}$ This suggests that reducing information risk, inherent risk and control risk is more important in Denmark than in the UK.

The study supports the hypothesized effects of agency relationships (Jensen and Meckling, 1976) with shareholders in Denmark, but in the UK this was specifically associated with companies that were not wholly family-owned and, to a lesser extent, with companies that have external shareholders. This implies a lower level of trust in UK companies with unrelated shareholders than in Denmark. This implies a lower level of trust in UK companies, but one difference between the two countries is that the needs of minority shareholders requiring audited accounts are protected under UK company law, which was not part of the proposal in Denmark. To a lesser extent, the benefit of audit to support agency relationships with the bank/lenders was a factor in Denmark but was not significant in the case of suppliers/creditors. However, these two results were reversed for the UK companies. The non significant result for the UK companies regarding demand from the bank/lenders conflicts with the findings of Tauringana and Clarke (2000) and Collis et al. (2004). However, the data for these previous studies was collected in 1999/2000, when audit exemption in the UK was fairly new, whereas banks now place greater emphasis on credit scoring and behavioural scoring (BBA, 2006). This requires further investigation.

\subsection{Limitations}

This study has focused on companies disclosing turnover in their financial statements since this is one of the key size tests and, unlike total assets and number of employees, turnover is less affected by industry. However, some caution is needed when drawing conclusions from 
the study as this means that UK companies filing abbreviated accounts were excluded and some of these may have chosen a voluntary audit of the statutory accounts for shareholders. Moreover, despite high response rates in both countries, the smallest companies were not fully represented. This is one of the main challenges in small business research and is caused by lack of representation in the available sampling frames, the relatively short life of many micro entities and the reluctance of owner-managers to participate due to business pressures (Curran and Blackburn, 2001). A further consideration is the relative lack of research into the accounting and auditing needs of SMEs compared to listed companies. This means explanatory theories are less developed and there is greater reliance on empirical data. A final point of note is that since this analysis is based on the directors' predicted audit decision, there is scope for future research to investigate actual practices. ${ }^{12}$

\subsection{Implications for preparers, users and regulators}

The results demonstrate that there are two groups within the small company category in the UK and Denmark with differing assurance needs and a significant proportion of directors consider the benefits of external audit outweigh the costs. This is good news for the accountancy profession (particularly auditors in small and medium-sized practices whose main fee income is from small companies). It will also be reassuring to those who use audited financial statements for assessing and monitoring lending and credit risk. However, lenders and creditors have the economic power to ensure that their information needs are met. Therefore, regulators may want to protect the needs of minority shareholders in small companies who require the assurance of an independent audit.

This study offers a model that can be tested in other jurisdictions. It has identified minor country differences in the determinants of voluntary audit, which suggests the European Commission's policy of harmonisation rather than standardisation should be retained. The results of this study should be of interest to the directors of small companies, the accountancy profession and those planning to introduce or review audit exemption options in national or EU company law. 


\section{References}

Abdel-Khalik, A. R. (1993), 'Why Do Private Companies Demand Auditing? A case for Organizational Loss of Control', Journal of Accounting, Auditing \& Finance, 8(1) Winter, pp. 31-52.

ACCA (1998), Small Company Audits, Research study by MORI, October, London: Association of Chartered Certified Accountants.

Accountancy (2003), 'DTI assesses threshold increase', January, p. 9.

Alexander, D., Britton, A. and Jorissen, A. (2007) International Financial Reporting and Analysis, $3^{\text {rd }}$ edition, London: Thomson Learning.

Barker, P. C. and Noonan, C. (1996), Small Company Compliance with Accounting Standards, Dublin: Dublin City University Business School.

BBA (2006) Credit Scoring for SMEs, 3 November, London: British Bankers' Association. Available from http://www.bba.org.uk/bba/jsp/polopoly.jsp?d=119\&a=7828\&artpage=1

Beckerlegge, J. (1999), 'The profession's view: Why the current threshold should be maintained', Accountancy Age, 23 September, p. 21.

BERR (2008), Small and Medium-sized Enterprise (SME) Statistics for the UK and Regions 2007, URN 08/92, August, Department for Business Enterprise and Regulatory Reform. Available from http://stats.berr.gov.uk/ed/sme

Cabinet Office (1999), Professional Policy Making for the Twenty-First Century, London: Cabinet Office.

Carey, P., Simnett, R. and Tanewski, G. (2000), 'Voluntary Demand for Internal and External Auditing by Family Businesses', Auditing: A Journal of Practice and Theory, 19 (Supplement), pp. 37-51.

Carsberg, B. V., Page, M. J., Sindall, A. J. and Waring, I. D. (1985), Small Company Financial Reporting, London: Prentice Hall International.

Chow, C. W. (1982), 'The demand for external auditing: size, debt and ownership influences', Accounting Review, April, pp. 272-291.

Christiansen, M. and Loft, A. (1992), 'Big players and small players, A study of increasing concentration in the Danish market for auditing services', European Accounting Review, 1(2), pp. 277-301.

Collis, J. (2003), Directors' Views on Exemption from the Statutory Audit, URN 03/1342, London: DTI, October. Available from http://www.berr.gov.uk/files/file25971.pdf 
Collis, J. (2008), Directors' Views on Accounting and Auditing Requirements for SMEs, London: BERR. Available from http://www.berr.gov.uk/whatwedo/businesslaw/corp-govresearch/current-research-proj/page18121.html

Collis, J. and Jarvis, R. (2000), How owner-managers use accounts, Research report, London: ICAEW. Available from http://icaew.com/index.cfm?route=111138

Collis, J. and Jarvis, R. (2002), Financial information and the management of small private companies, Journal of Small Business and Enterprise Development, 9(2), pp. 110-110.

Collis, J., Jarvis, R. and Skerratt, L. (2004), 'The Demand for the Audit in Small Companies in the UK', Accounting \& Business Research, 34(2), pp. 87-100.

Collis, J. and Jarvis, R. (2005), 'Auditor independence', Accounting \& Business, March, pp. 34-35.

Combarros, J. (2000), 'Accounting and financial audit harmonization in the European Union', European Accounting Review, 9(4), pp. 643-654.

Cormier, D., Magnan, M. and Van Velthoven, B. (2005), 'Environmental Disclosure Quality in Large German Companies: Economic Incentives, Public Pressures or Institutional Conditions?', European Accounting Review, 14(1), pp. 3-39.

Curran, J. and Blackburn, R. A. (2001), Researching the Small Enterprise, London: Sage.

Day, J. and Taylor, P. (2005), 'Accession to the European Union and the process of accounting and audit reform', Accounting in Europe, 2, pp. 3-21.

DCCA (2005), Report on the auditing requirement for B enterprises (small companies), English summary of 'Rapport om revisionspligten for B-virksomheder (små selskaber)', March, Copenhagen: Danish Commerce and Companies Agency. Available in Danish from http://www.eogs.dk/sw28131.asp

DCCA (2006), Note: The project on users and uses of small companies' financial statements, (internal document), 14 August, Copenhagen: Danish Commerce and Companies Agency.

Dichev, I. D. and Skinner, D. J. (2002), 'Large sample evidence on the debt covenant hypothesis', Journal of Accounting Research, 40(4) September, pp. 1091-1123.

DTI (1995), Accounting Simplifications - A Consultative Document, May, URN 95/669, London: Department of Trade and Industry.

DTI (1997), Small and Medium Enterprise (SME) Statistics for the United Kingdom, 1996, URN 97/92, July.

DTI (1999a), The Statutory Audit Requirement for Smaller Companies: A Consultative Document, URN 99/1115, October. 
DTI (1999b), Measures to cut red tape and reduce the burdens on business announced, P/99/471, 3 June.

DTI (2000a), Modern Company Law for a Competitive Economy: Developing the Framework, Company Law Review Steering Group, URN 00/656, March.

DTI (2000b), Red tape reform saves small companies millions, P/2000/244, 4 April.

DTI (2003), Raising the Thresholds, Consultation Document, URN 03/961, July.

Eaglesham, J. (2003), ‘Audit exemption for more companies', Financial Times, 18 November.

EC (n.d.), Facts and figures - SMEs in Europe. Available from http://ec.europa.eu/enterprise/entrepreneurship/facts_figures.htm

EC (2005), Report on impacts of raised thresholds defining SMEs, December, Brussels: DG Internal Market/Ramboll Management. Available from http://ec.europa.eu/internal_market/accounting/docs/studies/sme_thresholds_en.pdf

EC (2006), Comment from the International Auditing and Assurance Standards Board on the Exposure Draft: 'Improving the Clarity of IAASB Standards - October 2005', 13 March. Available from http://europa.eu.int/comm/internal_market/auditing

EC (2007), Communication from the Commission on a simplified business environment for companies in the areas of company law, accounting and auditing, Brussels, 10 July 2007. Available from http://ec.europa.eu/internal_market/company/simplification/index_en.htm

Ettredge, M., Simon, D., Smith, D. and Stone, M. (1994), 'Why do companies purchase timely quarterly reviews?', Journal of Accounting and Economics, 18, pp. 131-155.

Evans, L., Gebhardt, G. Hoogendoorn, M., Marton, J., Di Petra, R., Mora, A, Thinggård, F., Vehmanen, Petri and Wagenhofer, A. (2005), 'Problems and Opportunities of an International Financial Reporting Standard for Small and Medium-Sized Entities. The EAA FRSC's Comment on the IASB's Discussion Paper', Accounting in Europe, 2, pp. 23-45.

Fearnley, S. and Hines, T. (2003), 'The regulatory framework for financial reporting and auditing in the United Kingdom: the present position and impending changes', The International Journal of Accounting, 38, pp. 215-233.

Fearnley, S. and Page, M. (1994), 'Audit regulation - Where are we now?', Accountancy, March, 113(1207) p. 81.

FEE (2009) Survey on the Provision of Alternative Assurance and Related Services Across Europe, Brussels: Fédération des Experts comptables Européens. Available from http://www.fee.be/publications/default.asp?library_ref=4\&content_ref $=1088$ 
Field, A. (2000), Discovering Statistics Using SPSS for Windows, London: Sage.

Flower, J. (2004), European financial reporting: Adapting to a changing world, London, Palgrave Macmillan.

Frank, W. G. (1979), ‘An Empirical Analysis of International Accounting Principles', Journal of Accounting Research, Autumn, 17(2), pp. 593-605, cited in Gray, S. J. (1988), 'Towards a Theory of Cultural Influence on the Development of Accounting Systems Internationally' Abacus, 24(1), pp. 1-15.

Freedman, J. and Goodwin, M. (1993), 'The Statutory Audit and the Micro Company - An Empirical Investigation', in Merkin, R. M. (ed.) The Journal of Business Law, London: Sweet \& Maxwell.

Güntert, A. (2000), 'Audit Plaudits: Good news for companies and practitioners. Or is it?', Accountancy, June, pp. 75-76.

Gray, S. J. (1988), 'Towards a Theory of Cultural Influence on the Development of Accounting Systems Internationally', Abacus, 24(1), pp. 1-15.

Haller, A. and Löffelmann, J. V. (2008), Financial Reporting from the Perspective of Banks as a Major User Group of Financial Statements, Regensburg: University of Regensburg.

Haller, A. and Walton, P. (1998), 'Country Differences and Harmonization', in Walton, P., Haller, A. and Raffournier, B. (eds.), International Accounting, London: International Thomson Business Press.

Harding, F. (2000), 'What is the role of Europe in an increasingly harmonized world?' European Accounting Review, 9(4), pp. 593-601.

Hargreaves Heap, S. (1989), Rationality in Economics, Oxford: Blackwell.

Hofstede, G. (1980), Culture's Consequences: International Differences in Work Related Values, Thousand Oaks, CA: Sage Publications, cited in Gray, S. J. (1988), 'Towards a Theory of Cultural Influence on the Development of Accounting Systems Internationally', Abacus, 24(1), pp. 1-15.

Holm, C. and Warming-Rasmussen, B. (2008), 'An account of accountants: audit regulation and the audit profession in Denmark', in Quick, R., Turley, S. and Willekens, M. (eds.), Audit, Trust and Governance - Developing Regulation in Europe, Abingdon: Routledge.

Hossain, M., Perera, M. H. B. and Rahman, A. R. (1995), 'Voluntary Disclosure in the Annual Reports of New Zealand Firms', Journal of International and Financial Management and Accounting, 6(1) pp. 69-87.

IASC (1989), Framework for the Preparation and Presentation of Financial Statements, September, London: International Accounting Standards Committee. 
Jarvis, R. (1996), Users and Uses of Unlisted Companies' Financial Statements - A Literature Review, London: ICAEW.

Jarvis, R., Kitching, J., Curran, J. and Lightfoot, G. (1996), 'The Financial Management of Small Firms: An Alternative Perspective', ACCA Research Report 49, London: Certified Accountants Educational Trust.

Jensen, M. C. and Meckling, W. H. (1976), 'Theory of the Firm: Managerial Behavior, Agency Costs and the Ownership Structure', Journal of Financial Economics, 3, pp. 305360 .

Jones, C. (2003), 'Audit threshold: the impact', Accountancy, p. 92.

Kervin, J. B. (1992), Methods for Business Research, New York: HarperCollins.

Krejcie, R. V. and Morgan, D. W. (1970), 'Determining Sample Size for Research Activities', Educational and Psychological Measurement, 30, pp. 607-610.

Marriott, N., Collis, J. and Marriott, P. (2006), Qualitative review of the accounting and auditing needs of small and medium-sized companies and their stakeholders, London: Professional Oversight Board. Available from http://www.frc.org.uk/publications

Mitchell, P. (1999), 'The profession's view: Why the threshold should be raised', Accountancy Age, 23 September, p. 21.

Mueller, G. G. (1967), International Accounting, London: Macmillan, cited in Gray, S. J. (1988), 'Towards a Theory of Cultural Influence on the Development of Accounting Systems Internationally', Abacus, 24(1), pp. 1-15.

Nair, R. D. and Frank, W. G. (1980), 'The impact of disclosure and measurement practices on international accounting classifications', Accounting Review, July, pp. 426-450.

Nobes, C. W. (1993), 'A Judgemental International Classification of Financial Reporting Practices', Journal of Business Finance and Accounting, 10(1), pp. 1-19.

Nobes, C. W. (1998), 'Towards a general model of the reasons for international differences in financial reporting', Abacus, 34(2), pp. 162-187.

NRF (2006), Mandatory SME Audit Rules Relaxed in Denmark, News, 26 March. Available from http://www.nrfaccount.se/news.asp?id=60

Owen, G. and Law, J. (eds.) (2005), Dictionary of Accounting, $3^{\text {rd }}$ edition, Oxford: Oxford University Press.

Page, M. J. (1984), 'Corporate Financial Reporting and the Small Independent Company', Accounting and Business Research, 14(55), pp. 271-282. 
Paoloni, M. and Demartini, P. (1997), 'Small company financial reporting: Users and information needs', Annual Congress of the European Accounting Association, Seville, April.

POB (2006), Review of How Accountants Support the Needs of Small and Medium-sized Companies and their Stakeholders, London: Professional Oversight Board, March.

Power, M. (1997), The Audit Society - Rituals of Verification, Oxford: Oxford University Press.

Pratten, C. (1998), The Uses of the Accounts of Small and Medium-sized Companies and the Effects of the Audit Exemption Regime, London: ICAEW.

Prencipe, A. (2004), 'Proprietary Costs and Determinants of Voluntary Segment Disclosure: Evidence from Italian Listed Companies', European Accounting Review, 13(2), pp. 319-340.

Ramos, M. (2003), 'Auditors' responsibility for fraud detection', Journal of Accountancy, 195, pp. 28-37.

Riistama V. and Vehmanen P. (2004), Globally applicable conceptual framework for small and medium-sized entities, cited in Evans et al. (2005) 'Problems and Opportunities of an International Financial Reporting Standard for Small and Medium-Sized Entities. The EAA FRSC's Comment on the IASB's Discussion Paper', Accounting in Europe, 2, pp. 23-45.

Rose, A. (2003), 'Raising audit threshold will raise fraud risk', The Times, p. 33.

SBS (2004), Small and Medium Enterprises (SME) Statistics for UK 2003, URN 04/92, London: Small Business Service.

Seow, J.-L. (2001), 'The Demand for the UK Small Company Audit - An Agency Perspective', International Small Business Journal, 19(2), pp. 61-78.

Simunic, D. A. and Stein, M. T. (1987), Product Differentiation in Auditing: A Study of Auditor Effects in the Market for New Issues. The Canadian Certified General Accountants Research Foundation.

SPA (2003), The Company Law Review - The Beneficial Impact of Raising Audit Thresholds from $£ 350,000$ to $£ 1,000,000$, June, Great Missenden: The Society of Professional Accountants. Available from http://www.spa.org.uk

Sundgren, S. (1998), 'Auditor choices and auditor reporting practices: evidence from Finnish small firms', The European Accounting Review, 7(3), pp. 441- 465.

Svensson, B. (2003), Useful Financial Accounting Information when Assessing Small and Medium-Sized Enterprise (SME) Creditworthiness, Dissertation, Uppsala University, Sweden. 
Tauringana, V. and Clarke, S. (2000), 'The demand for external auditing: managerial share ownership, size, gearing and liquidity influences', Managerial Auditing Journal, 15(4), pp. 160-168.

Watson, A., Shrives, P. and Marston, C. (2002), 'Voluntary disclosure of accounting ratios in the UK', British Accounting Review, 34, pp. 289-313.

Weber, M. (1968), Economy and Society, New York: Bedminster Press. 


\section{Chart 1}

Turnover thresholds for audit exemption for EU-25 in 2005

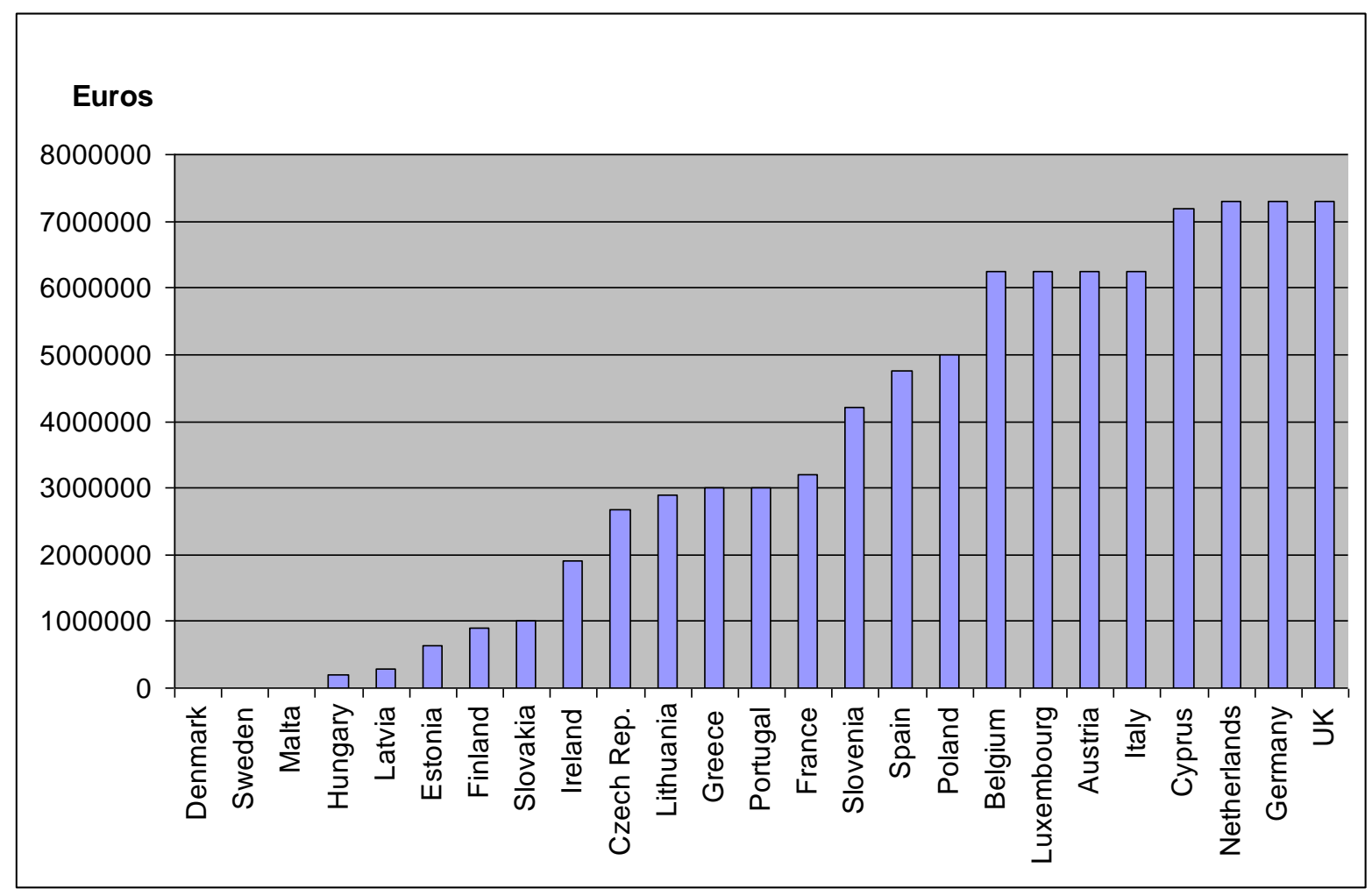

Adapted from EC, 2006, p. 7 and EC, 2005

\section{Chart 2}

Changes in the financial thresholds for audit exemption in the UK $1994-2008$

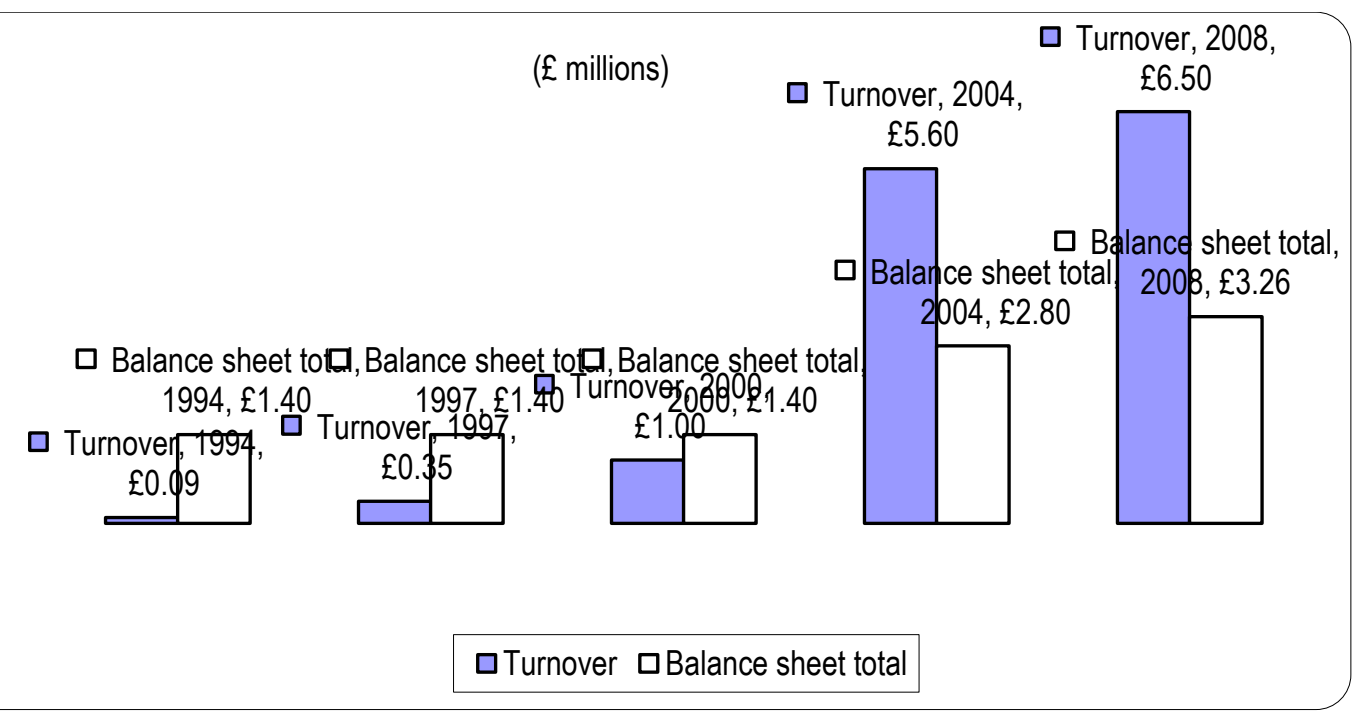


Table 1

Small companies as a percentage of total companies in EU-19

\begin{tabular}{|lc|}
\hline Country & \% small in 2003 \\
\hline Estonia & 97 \\
Belgium, Spain, Sweden, UK & 95 \\
Finland, France, Ireland & 94 \\
Denmark & 93 \\
Austria & 90 \\
Germany, Netherlands & 89 \\
Greece, Italy, Portugal & 85 \\
Czech Republic & 83 \\
Slovenia & 78 \\
Luxembourg & 77 \\
Hungary & 67 \\
Average & $\mathbf{9 4}$ \\
\hline
\end{tabular}

Adapted from EC, 2006, p. 7

Table 2

EU maxima for audit exemption

\begin{tabular}{|lcccc|}
\hline & 1998 & 1999 & 2003 & 2008 \\
\hline Turnover & $€ 5.0 \mathrm{~m}$ & $€ 6.25 \mathrm{~m}$ & $€ 7.30 \mathrm{~m}$ & $€ 8.8 \mathrm{~m}$ \\
Balance sheet total & $€ 2.5 \mathrm{~m}$ & $€ 3.125 \mathrm{~m}$ & $€ 3.65 \mathrm{~m}$ & $€ 4.4 \mathrm{~m}$ \\
Average number of employees & 50 & 50 & 50 & 50 \\
\hline
\end{tabular}

Adapted from DTI, 1999a, Annex B; DTI, 2000, p. 270; and EC, 2006, p. 6 
Table 3

Audit exemption thresholds in EU, Norway and Switzerland in 2009

\begin{tabular}{|c|c|c|}
\hline Audit exemption thresholds & Countries & $\%$ \\
\hline $\begin{array}{l}\text { Maximum or near maximum thresholds: } \\
\text { (Austria, Belgium, Germany, Ireland, Italy, Luxembourg, the Netherlands, Romania, } \\
\text { Slovenia, Switzerland }{ }^{1} \text {, United Kingdom) }\end{array}$ & 11 & 38 \\
\hline $\begin{array}{l}\text { Balance sheet total between } € 2.5 \mathrm{~m} \text { and } € 3 \mathrm{~m} \\
\text { Net turnover between } € 5 \mathrm{~m} \text { and } € 5.7 \mathrm{~m} \\
\text { (Greece, Poland and Spain) }\end{array}$ & 3 & 10 \\
\hline $\begin{array}{l}\text { Balance sheet total between } € 1 \mathrm{~m} \text { and } € 1.8 \mathrm{~m} \\
\text { Net turnover between } € 2 \mathrm{~m} \text { and } € 3.1 \mathrm{~m} \\
\text { (Czech Republic, France (except for } \mathrm{SA}^{2} \text { ), Lithuania, Portugal and Slovak Republic }{ }^{1} \text { ) }\end{array}$ & $4(1)$ & 14 \\
\hline $\begin{array}{l}\text { Balance sheet total: between } € 0.5 \mathrm{~m} \text { and } € 0.9 \mathrm{~m} \\
\text { Net turnover: between } € 1 \mathrm{~m} \text { and } € 1.8 \mathrm{~m} \\
\text { (Estonia }{ }^{1} \text { ) }\end{array}$ & 1 & 4 \\
\hline $\begin{array}{l}\text { Balance sheet total: between } € 0.1 \mathrm{~m} \text { and } € 0.5 \mathrm{~m} \\
\text { Net turnover: between } € 0.2 \mathrm{~m} \text { and } € 0.1 \mathrm{~m} \\
\text { (Bulgaria, Denmark }^{1} \text {, Finland } \\
\text {, Hungary } \\
{ }^{1} \text { and Latvia }\end{array}$ & 5 & 17 \\
\hline $\begin{array}{l}\text { Balance sheet total/ net turnover: } € 0 \\
\left(\text { Cyprus }^{4}, \text { France }\left(\text { for } \mathrm{SA}^{2}\right), \text { Norway, Malta }\right. \\
\end{array}$ & 5 & 17 \\
\hline Total & 29 & 100 \\
\hline
\end{tabular}

Notes:

${ }^{1}$ Introduction or increase in 2007, 2008 or 2009

${ }^{2}$ Société Anonyme

${ }^{3}$ Decrease in 2007

${ }^{4}$ For tax purposes

${ }^{5}$ Expected to increase to maximum thresholds in 2010

Adapted from FEE, 2009, p. 7

Table 4

Description of variables

\begin{tabular}{|llcc|}
\hline Variable & Description & Expected sign & Hypothesis tested \\
\hline VOLAUDIT & Whether company would have a voluntary audit if eligible (DV) & & \\
TURNOVER & Size of company as measured by turnover & + & $\mathrm{H} 1$ \\
COST & Extent of agreement that audit cost is a substantial expense & - & $\mathrm{H} 2$ \\
CHECK & Extent of agreement that audit provides a beneficial check on & + & $\mathrm{H} 3$ \\
& accounting records and systems & + & $\mathrm{H} 4$ \\
QUALITY & $\begin{array}{l}\text { Extent of agreement that audit improves the quality of the } \\
\text { financial information }\end{array}$ & + & $\mathrm{H} 5$ \\
SHAREHLDRS & Whether audit is required for shareholders & - & $\mathrm{H} 5$ \\
FAMILY & Whether company is wholly family-owned & + & $\mathrm{H} 5$ \\
EXOWNERS & Whether company has external owners without access to internal & + & $\mathrm{H} 6$ \\
& financial information & + & \\
BANK & UK: Whether the statutory accounts are given to the bank/lenders & + & $\mathrm{H} 7$ \\
& Denmark: Whether audit is required for the bank/lenders & & \\
\hline
\end{tabular}


Table 5

Descriptive statistics

\begin{tabular}{|l|rrrrr|rrrrr|}
\hline Variable & \multicolumn{4}{|c}{ UK } & \multicolumn{4}{c|}{ Denmark } \\
& $N$ & Min & Max & Mean & SD & $N$ & Min & Max & Mean & $S D$ \\
\hline VOLAUDIT & 772 & 0 & 1 & N/A & N/A & 509 & 0 & 1 & N/A & N/A \\
TURNOVER & 790 & $<0.01$ & 4.74 & 0.69 & 1.119 & 530 & $<0.5$ & $\leq 58$ & N/A & N/A \\
COST & 474 & 1 & 5 & 3.09 & 1.526 & 523 & 1 & 4 & 2.94 & .895 \\
CHECK & 697 & 1 & 5 & 4.05 & 1.191 & 523 & 1 & 4 & 3.01 & .834 \\
QUALITY & 687 & 1 & 5 & 3.35 & 1.379 & 512 & 1 & 4 & 2.96 & .819 \\
SHAREHLDRS & 529 & 0 & 1 & N/A & N/A & 542 & 0 & 1 & N/A & N/A \\
FAMILY & 785 & 0 & 1 & N/A & N/A & 537 & 0 & 1 & N/A & N/A \\
EXOWNERS & 722 & 0 & 1 & N/A & N/A & 519 & 0 & 1 & N/A & N/A \\
BANK & 790 & 0 & 1 & N/A & N/A & 542 & 0 & 1 & N/A & N/A \\
CREDITORS & 497 & 0 & 1 & N/A & N/A & 542 & 0 & 1 & N/A & N/A \\
\hline
\end{tabular}

N/A = Calculation of the mean and the standard deviation are not appropriate for variables measured on an unequal interval or ordinal scale

Table 6

Spearman's correlation matrix of ratio and ordinal variables

\begin{tabular}{|l|cccc|cccc|}
\hline Variable & \multicolumn{4}{|c|}{ UK } & \multicolumn{4}{c|}{ Denmark } \\
& TURNOVER & COST & CHECK & QUALITY & TURNOVER & COST & CHECK & QUALITY \\
\hline TURNOVER & 1.000 & & & & 1.000 & & \\
COST & $-.095^{*}$ & 1.000 & & & .018 & 1.000 & \\
CHECK & $.106^{* *}$ & -.039 & 1.000 & & $.145^{* *}$ & $-.280^{* *}$ & 1.000 \\
QUALITY & $.112^{* *}$ & -.041 & $.606^{* *}$ & 1.000 & .025 & $-.193^{* *}$ & $.673^{* *}$ & 1.000 \\
\hline
\end{tabular}

* Correlation is significant at the 0.05 level (2-tailed)

** Correlation is significant at the 0.01 level (2-tailed)

Table 7

Key characteristics of the sample companies

\begin{tabular}{|l|ll|ll|}
\hline Characteristic & \multicolumn{2}{|c|}{$U K(N=790)$} & \multicolumn{2}{c|}{ Denmark $(N=553)$} \\
\hline Turnover & Up to $£ 1 \mathrm{~m}$ & $80 \%$ & Up to 12m DKK & $82 \%$ \\
Balance sheet total & Up to $£ 1.4 \mathrm{~m}$ & $89 \%$ & Up to 12m DKK & $88 \%$ \\
Employees & Up to 10 & $78 \%$ & Up to 10 & $80 \%$ \\
Total shareholders & 1 or 2 & $69 \%$ & 1 or 2 & $84 \%$ \\
External ownership & Presence of shareholder(s) & $17 \%$ & Presence of shareholder(s) & $26 \%$ \\
& without access to internal & & without access to internal & \\
& financial information & & financial information & \\
Family ownership & Wholly family-owned & $68 \%$ & Wholly family-owned & $58 \%$ \\
\hline
\end{tabular}


Table 8

Mann-Whitney tests on non-parametric ratio and ordinal variables

\begin{tabular}{|l|cccc|cccc|}
\hline Variable & \multicolumn{4}{|c|}{$U K$} & \multicolumn{4}{c|}{ Denmark } \\
& $N$ & Mann-Whitney $U$ & $Z$ & $p$ & $N$ & Mann-Whitney $U$ & $Z$ & $p$ \\
\hline TURNOVER & 772 & 40203.5 & -10.731 & .000 & 489 & 23997.5 & -3.017 & .003 \\
COST & 470 & 20276.0 & -5.095 & .000 & 488 & 14903.0 & -9.587 & .000 \\
CHECK & 682 & 37629.0 & -8.519 & .000 & 488 & 15217.0 & -9.751 & .000 \\
QUALITY & 672 & 32083.0 & -9.864 & .000 & 478 & 16508.0 & -8.249 & .000 \\
\hline
\end{tabular}

Table 9

Chi-square tests on nominal variables

\begin{tabular}{|l|cccc|cccc|}
\hline Variable & \multicolumn{4}{|c|}{ UK } & \multicolumn{4}{c|}{ Denmark } \\
& $N$ & Chi-square* & $d f$ & $p$ & $N$ & Chi-square* & $d f$ & $p$ \\
\hline SHAREHLDRS & 517 & 57.770 & 1 & .000 & 507 & 86.736 & 1 & .000 \\
FAMILY & 767 & 32.212 & 1 & .000 & 498 & 2.392 & 1 & .122 \\
EXOWNERS & 706 & 16.573 & 1 & .000 & 484 & 0.229 & 1 & .632 \\
BANK & 772 & 48.452 & 1 & .000 & 507 & 51.822 & 1 & .000 \\
CREDITORS & 488 & 61.313 & 1 & .000 & 507 & 33.648 & 1 & .000 \\
\hline
\end{tabular}

*With Yate's correction for continuity 
Table 10

Demand for voluntary audit: Sufficiency of turnover

\begin{tabular}{|c|c|c|c|c|c|c|c|c|}
\hline \multirow[t]{2}{*}{ Variable } & \multicolumn{4}{|c|}{$U K$} & \multicolumn{4}{|c|}{ Denmark } \\
\hline & $B$ & $S E$ & Wald & $p$ & $B$ & $S E$ & Wald & $p$ \\
\hline Panel A Size & & & & & & & & \\
\hline TURNOVER & .834 & .097 & 73.909 & .000 & .182 & .058 & 9.725 & .002 \\
\hline Constant & -.790 & .092 & 74.183 & .000 & -.987 & .202 & 23.937 & .000 \\
\hline Panel B Size and management factors & & & & & & & & \\
\hline TURNOVER & .592 & .117 & 25.526 & .000 & .258 & .077 & 11.244 & .001 \\
\hline COST & -.356 & .079 & 20.553 & .000 & -1.150 & .158 & 52.820 & .000 \\
\hline CHECK & .377 & .132 & 8.199 & .004 & .911 & .233 & 15.316 & .000 \\
\hline QUALITY & .558 & .107 & 27.059 & .000 & .663 & .218 & 9.284 & .002 \\
\hline Constant & -2.677 & .520 & 26.530 & .000 & -2.859 & .818 & 12.206 & .000 \\
\hline Panel C Size and agency factors & & & & & & & & \\
\hline TURNOVER & .773 & .176 & 19.217 & .000 & .121 & .006 & 3.372 & .066 \\
\hline SHAREHLDRS & 1.207 & .354 & 11.606 & .001 & 1.456 & .224 & 42.287 & .000 \\
\hline FAMILY & -.799 & .277 & 8.289 & .004 & & & No co & ation \\
\hline EXOWNERS & .937 & .386 & 5.892 & .015 & & & No co & ation \\
\hline BANK & .362 & .288 & 1.574 & .210 & .718 & .252 & 8.143 & .004 \\
\hline CREDITORS & 1.171 & .368 & 10.103 & .001 & .790 & .291 & 7.370 & .007 \\
\hline Constant & -2.072 & .411 & 25.467 & .000 & -2.085 & .278 & 56.083 & .000 \\
\hline
\end{tabular}

Model summaries:

$$
\begin{aligned}
\text { Panel A } & \mathrm{N}=772 \\
& \text { Chi-square 112.648, df 1, } p .000 \\
& \text { Pseudo } \mathrm{R}^{2} .182 \\
\text { Panel B } & \mathrm{N}=451 \\
& \text { Chi-square } 158.923 \text {, df } 4, p .000 \\
& \text { Pseudo } \mathrm{R}^{2} .396 \\
\text { Panel C } & \mathrm{N}=366 \\
& \text { Chi-square } 138.952 \text {, df 6, } p .000 \\
& \text { Pseudo } \mathrm{R}^{2} .421
\end{aligned}
$$$$
\mathrm{N}=489
$$$$
\text { Chi-square 9.873, df 1, } p .002
$$$$
\text { Pseudo } \mathrm{R}^{2} .027
$$

$\mathrm{N}=432$

Chi-square 177.351 , df $4, p .000$

Pseudo $\mathrm{R}^{2} .456$

$\mathrm{N}=487$

Chi-square 115.269, df 4, $p .000$

Pseudo $\mathrm{R}^{2} .286$

\section{Table 11}

\section{Demand for voluntary audit: Size, management and agency factors}

\begin{tabular}{|l|rrrr|rrrr|}
\hline & \multicolumn{4}{|c|}{ UK } & \multicolumn{4}{c|}{ Denmark } \\
Variable & \multicolumn{1}{|c}{$B$} & \multicolumn{1}{|c}{ SE } & Wald & \multicolumn{1}{c|}{$p$} & \multicolumn{1}{c|}{$B$} & \multicolumn{1}{c|}{ SE } & \multicolumn{1}{c|}{ Wald } & $p$ \\
\hline TURNOVER & .604 & .196 & 9.465 & .002 & .200 & .082 & 5.912 & .015 \\
COST & -.296 & .112 & 6.968 & .008 & -1.106 & .170 & 42.264 & .000 \\
CHECK & .343 & .230 & 2.222 & .136 & .796 & .248 & 10.259 & .001 \\
QUALITY & .509 & .180 & 8.001 & .005 & .549 & .231 & 5.663 & .017 \\
SHAREHLDRS & .255 & .490 & .272 & .602 & 1.242 & .277 & 20.067 & .000 \\
FAMILY & -1.289 & .393 & 10.754 & .001 & & & No correlation \\
EXOWNERS & .945 & .520 & 3.299 & .069 & & & No correlation \\
BANK & .140 & .382 & .133 & .715 & .519 & .313 & 2.743 & .098 \\
CREDITORS & .850 & .478 & 3.161 & .075 & 517 & .355 & 2.114 & .146 \\
Constant & -2.672 & .857 & 9.723 & .002 & -3.109 & .880 & 12.474 & .000 \\
\hline
\end{tabular}

Model summaries: $\quad \mathrm{N}=254$

Chi-square 130.334, df 9, p .000

Pseudo $\mathrm{R}^{2} .538$
$\mathrm{N}=431$

Chi-square 216.360, df 7,p .000

Pseudo $\mathrm{R}^{2} .534$ 


\footnotetext{
${ }^{1}$ Since 2005, group companies with a listing on an EU regulated stock exchange have been required to prepare their consolidated accounts using IFRS.

${ }^{2} 2003$ is the latest year for which figures were available. The original publication notes that the statistics are merely indicative since the database contained only a limited part of the population of companies.

${ }^{3}$ These comprised the original members of the European Economic Community created by the Treaty of Rome in 1957: Belgium, France, Germany, Italy, Luxembourg and the Netherlands. They were joined by Denmark, Ireland and the UK in 1973; by Greece in 1981; by Portugal and Spain in 1986; by Austria, Finland and Sweden in 1995; and by Cyprus, Czech Republic, Estonia, Hungary, Latvia, Lithuania, Malta, Poland and Slovakia in 2004. By the end of 2007, the total had risen to 27 with the accession of Bulgaria and Romania.

${ }^{4}$ As a result of further restructuring in 2009, BERR was replaced by the Department for Business, Innovation and Skills (BIS).

${ }^{5}$ This replaced the Companies Act 1985.

${ }^{6}$ The Companies Act 2006 (c.46, Part 15, Chapter 10) allows qualifying small and medium-sized companies to register either full or abbreviated financial statements (sections 444-5), but they must provide full financial statements for their shareholders. Under section 449, if the company is not exempt from audit or has chosen voluntary audit, the abbreviated accounts must be accompanied by a special auditor's report stating that the company is entitled to deliver abbreviated accounts and they have been prepared in accordance with the regulations. The special report must set out the full auditor's report if the latter was qualified or stated that accounts, records or returns were inadequate; accounts did not agree with records and returns; failed to obtain necessary information.

${ }^{7}$ Latest survey evidence puts the figure at $77 \%$ for small companies and $88 \%$ for medium-sized companies (Collis, 2008).

${ }^{8}$ At the start of 2003, the population of small companies was 873,320 (SBS, 2004, Table 2) and a sample of 790 greatly exceeds the minimum acceptable size of 384 (Krejcie and Morgan, 1970, p. 608).

${ }^{9}$ SHAREHLDRS, FAMILY, EXOWNERS, BANK and CREDITORS are not suitable for this procedure as they are measured on a nominal scale.

${ }^{10}$ Views on adoption of any alternative form of assurance were not collected in the UK. However, this was addressed subsequently by Collis (2008).

${ }^{11}$ The definition of 'small' was higher than that used by Collis et al. (2004) due to increases in the EU maxima.

${ }^{12}$ This was done in the UK by Collis (2008).
} 